\title{
Correction to: Novel authorship verification model for social media accounts compromised by a human
}

\author{
Suleyman Alterkavı ${ }^{1}$ (D) $\cdot$ Hasan Erbay ${ }^{2}$ \\ Published online: 16 February 2021 \\ (C) Springer Science+Business Media, LLC, part of Springer Nature 2021
}

\section{Correction to: Multimedia Tools and Applications (2021) https://doi.org/10.1007/s11042-020-10361-2}

The author name "Suleyman Alterkavı" was incorrectly presented in the original publication. The original article has been corrected.

Publisher's note Springer Nature remains neutral with regard to jurisdictional claims in published maps and institutional affiliations.

The online version of the original article can be found at https://doi.org/10.1007/s11042-020-10361-2

Suleyman Alterkav1

sleman-terkawi@hotmail.com

Hasan Erbay

herbay@thk.edu.tr

1 University of Kırıkkale, Kırıkkale, Turkey

2 Computer Engineering Department, Engineering Faculty, University of Turkish Aeronautical Association, Ankara 06790 Etimesgut, Turkey 